\title{
ЯКІСНІ ПОКАЗНИКИ ЯЄЦЬ М'ЯСО-ЯЄЧНИХ КУРЕЙ РІЗНОГО ГЕНЕЗИСУ
}

\author{
Хвостик Віктор Павлович \\ доктор сільськогосподарських наук \\ Інститут розведення і генетики тварин імені М.В.Зубця НАAН (с. Чубинське, Україна) \\ ORCID: 0000-0002-8107-4831 \\ E-mail: lab29@meta.ua
}

Бондаренко Юрій Васильович доктор біологічних наук, професор Сумський національний аграрний університет (м. Суми, Україна) ORCID: 0000-0002-5746-379X E-mail: yuvbond@ukr.net

Досліджено широкий комплекс морфологічних ознак яєць курей вихідної материнської форми, нащадків першогодругого поколінь, створеної синтетичної популяції у ході проведення досліджень з вивчення ефрективності схрещування півнів імпортних м'ясних кросів із м'ясо-яєчними самками вітчизняної селекиії. Якісні показники яєць у кількості 30 штук від кожної генотипової групи курей визначали у віці 30 тижнів. У курей вихідної материнської форми такі ознаки як маса яєць, діаметри яєць та жовтку, висота жовтку, маса та відносна доля жовтку були вірогідно більшими як порівняти з нащадками першої генерації. Тоді як, у гібридів першого покоління висота білка, індекс білка та його маса характеризувалися вищими значеннями за порівняння з курми вихідної материнської форми. У нащадків другого покоління, батьками яких були півні кросу „Кобб-500”, маса яєць та білка були більшими за порівняння з ровесницями, для отримання яких використовували самців кросу „Росс-308”. У м'ясо-ясчних курей вихідної форми індекс формми більший на 2,11-2,86 \% (P>0,95$0,99)$ порівняно з гібридами $F_{2}$. Маса яєць, їх довжина та ширина, індекс форми характеризувалися слабкою мінливістю $(2,46-9,06 \%)$ й у нащадків $F_{2}$, у більшості випадків, були більшими, ніж у м'ясо-яєчних курей вітчизняної селекції. За висотою й індексу білка значної відмінності між птицею різних груп $F_{2}$ не встановлено. За масою жовтку вірогідної різниці між курми різного генезису $F_{2}$ не досягнуто. На масу жовтку генотип вплинув на 12,96 \% $(P<0,001)$. Якісні показники жовтку мали слабкі коеффіцієнти мінливості (3,26-10,01 \%) й у гібридних курей $F_{2}$ були дещо більшими, ніж у м'ясо-яєчних субпопулячії „К”. У м'ясо-ясчної птиці вихідної материнської форми маса шкаралупи більша на 0,47-0,59 г (P>0,99-0,999) порівняно з потомками другого покоління. У курей створеної синтетичної популяції більша маса яєць визначила відповідно і вищі значення деяких морфоологічних ознак. Відмічено вірогідні відмінності з птицею інших генотипових груп за подовжнім діаметром яєць, індексом форми, абсолютною масою білка, індексом жовтку, масою жовтку, долею шкаралупи.

Ключові слова: м'ясо-яєчні кури, схрещування, якість яєць, морфологічні ознаки, білок, жовток, шкаралупа.

DOI: https://doi.org/10.32845/bsnau.lvst.2020.4.13

Створення нових чи покращення існуючих селекційно-значимих форм птиці повинно супроводжуватися різноманітним вивченням їх господарсько-біологічних особливостей. У курівництві одним із фунндаментальних напрямків такої роботи є вивчення оцінки якості яєць птиці, яка виступає необхідною складовою їх селекційного поліпшення та $є$ запорукою одержання кондиційного життєздатного молодняку племінного призначення [1-5].

Ефективною селекція за якісними ознаками яєць може бути на початку яйцекладки і повинна спрямовуватися, передусім, на зменшення у стаді особин з низькими показниками. Це дасть змогу своєчасно вибракувати небажаних генотипів та досяпти стартового укрупнення яєць. Деякі кури зносять відносно крупні яйця на початку продуктивного періоду і помірно крупні - наприкінці. Такі особини представляють особливу селекційну цінність, тому що дають однорідні за масою крупні яйця [6]. Маса яєць, як відомо, є одним з основних якісних показників інкубаційних яєць. Зі зміною маси яйця багато у чому змінюеться і його якість [7].

Метою досліджень було дослідити морфоологічні якості яєць на початку періоду несучості курей вихідної материнської форми та нащадків ряду поколінь, отриманих за різних методів розведення, у ході досліду з вивчення ефективності схрещування півнів імпортних м'ясних кросів з м'ясо-яєчними самками вітчизняної селекції.

Матеріали та методи досліджень. За схрещування півнів м'ясних кросів "Кобб-500" та "Росс-308" з м'ясояєчними курми отримали нащадків першої генерації $\left(F_{1}\right)$ відповідно груп "К-1" та "К-2". За зворотного схрещування переярих півнів кросів "Кобб-500" та "Росс-308" з молодими гібридними курми $\mathrm{F}_{1}$ груп "К-1" і "К-2" одержали гібридів другого покоління $\left(\mathrm{F}_{2}\right)$ відповідно груп "К-51" та "К-32". Крім цього, гібриди $\mathrm{F}_{1}$ груп "К-1" і "К-2" розводилися "у собі", внаслідок чого отримали їх нащадків $F_{2}$ груп "К-11" та "К-22". Шляхом об'єднання курей $F_{2}$ різних генотипових груп створено гетерогенну синтетичну популяцію "К-5" [8].

Морфологічні якості яець (по 30 штук від кожної групи, вік курей - 30 тижнів) вивчали у м'ясо-яєчних курей субпопуляції "К" (синтетичний корніш з білим оперенням) вихідної материнської форми; нащадків першого (групи "К-1" та "К-2") та другого (групи "К-11","К-22","К-51" і "К-32") поколінь, синтетичної популяції "К-5" за відомою методикою [9].

Результати досліджень. Результати визначення фізико-морфологічних ознак яєць м'ясо-яєчних курей $F_{10}$ локальної субпопуляції „К”, гібридів $F_{1}$ груп „K-1” i „K-2” наведено у таблицях 1-3. Наводимо лише відмінності вірогідного характеру між дослідженими групами курей за вивченими морфологічними ознаками яєць.

Оцінка морфрологічних якостей яєць не зводиться лише до їх зовнішнього огляду, а проводиться детальний 
аналіз внутрішнього умісту яєць. Тільки за розбивання яєць ретельного вивчення їх умісту можна більш об'єктивно судити про якість білку, жовтку та шкаралупи [10]. Маса яєць є одним з основних яєчної продуктивності [11]. У курей вихідної материнської форми маса яєць більша на 2,27 г $(P>0,99)$, ніж у гібридних нащадків $F_{1}$ групи „К-1”. Діаметри яєць у курей субпопуляції „К” та гібридів $F_{1}$ групи „К-2” виявилися більшими порівняно з групою „К-1”: подовжній - на 1,22-1,24 мм (2,31-2,35 \%, P>0,99), поперечний - на 0,7 мм $(1,67 \%$, Р>0,95). Коефріцієнт мінливості маси яєць невисокий - 8,30-9,85 \% й у гібридів вищий, ніж у матерів.

Морфологічні ознаки яєць м'ясо-яєчних курей субпопуляції „К”, $\mathrm{F}_{10}$

Таблиця 1

\begin{tabular}{|l|c|c|c|c|}
\hline \multicolumn{1}{|c|}{ Показники } & $\bar{X}$ & $\pm S_{\bar{X}}$ & $\delta$ & \multicolumn{1}{c|}{$\mathrm{Cv}, \%$} \\
\hline Маса яєць, г & 52,67 & 0,56 & 4,37 & 8,30 \\
\hline Індекс форми, \% & 78,69 & 0,42 & 3,26 & 4,14 \\
\hline Маса білка, г & 31,16 & 0,42 & 3,27 & 10,49 \\
\hline Індекс білка, \% & 13,35 & 0,28 & 2,17 & 16,25 \\
\hline Доля білка, \% & 59,08 & 0,27 & 2,07 & 3,50 \\
\hline Маса жовтку, г & 14,64 & 0,15 & 1,13 & 7,72 \\
\hline Індекс жовтку, \% & 52,13 & 0,32 & 2,47 & 4,74 \\
\hline Доля жовтку, \% & 27,87 & 0,22 & 1,69 & 6,06 \\
\hline Співвідношення білок/жовток & 2,13 & 0,02 & 0,19 & 8,92 \\
\hline Маса шкаралупи, г & 6,86 & 0,10 & 0,79 & 1,52 \\
\hline Доля шкаралупи, \% & 13,05 & 0,17 & 1,29 & 9,89 \\
\hline
\end{tabular}

У „росівських” курей групи „К-2” маса білка більша на 1,71 г (або 5,67 \%, Р>0,95), ніж у „кобівських” групи „К-1”. Висота білка, індекс білка та його маса характеризувалися середніми значеннями мінливості $(10,49-20,91 \%)$ й у гібридної птиці були вищими порівняно з вихідною материнською формою.
У м'ясо-яєчних курей локальної субпопуляції „К” великий діаметр жовтку більший, ніж у гібридів $F_{1}$, на 1,47-1,76 мм (або 3,73-4,50 \%, Р>0,999), малий - на 1,03-1,46 мм $(2,77-3,98 \%$, Р>0,99-0,999). Більшою у м'ясо-яєчних курей була і висота жовтку. Перевага над потомками $\mathrm{F}_{1}$ становила 0,46-0,93 мм ( $P>0,99-0,999)$.

Таблиця 2

Морфологічні ознаки яєць гібридних курей $\mathrm{F}_{1}$ групи „К-1”

\begin{tabular}{|l|c|c|c|c|}
\hline \multicolumn{1}{|c|}{ Показники } & $\bar{X}$ & $\pm \boldsymbol{S}_{\bar{X}}$ & $\delta$ & $\mathrm{Cv}, \%$ \\
\hline Маса яєць, г & 50,40 & 0,59 & 4,56 & 9,05 \\
\hline Індекс форми, \% & 79,17 & 0,42 & 3,20 & 4,04 \\
\hline Маса білка, г & 30,15 & 0,45 & 3,48 & 11,54 \\
\hline Індекс білка, \% & 13,92 & 0,38 & 2,91 & 20,91 \\
\hline Доля білка, \% & 59,75 & 0,35 & 2,66 & 4,45 \\
\hline Маса жовтку, г & 13,57 & 0,18 & 1,41 & 10,39 \\
\hline Індекс жовтку, \% & 52,66 & 0,35 & 2,66 & 5,05 \\
\hline Доля жовтку, \% & 26,98 & 0,30 & 2,29 & 8,49 \\
\hline Співвідношення білок/жовток & 2,24 & 0,04 & 0,28 & 12,50 \\
\hline Маса шкаралупи, г & 6,67 & 0,09 & 2,71 & 10,64 \\
\hline Доля шкаралупи, \% & 13,27 & 0,14 & 3,11 & 8,36 \\
\hline
\end{tabular}

Більші значення якісних ознак жовтку у м'ясо-яєчних курей вихідної материнської форми обумовили й більшу його масу. Маса жовтку у них більша на 7,88-9,01 \% (P>0,999), ніж у гібридів $F_{1}$ обох груп. Відносна доля білка в яйцях курей досліджених груп (59,08-61,05 \%) добре відповідає усталеним середнім значенням 56-62 \% [12]. У курей групи „К-2” доля білка вища на 1,30-1,97 \% (P>0,95-0,999) порівняно з іншою птицею.

Вміст жовтку в яйцях курей досліджених груп відповідає даним [2], в яких дана величина коливається від $26 \%$ до $32 \%$. За відносним умістом жовтку між курми різних генотипів встановлено суттєві відмінності. Так, у м'ясояєчних курей субпопуляції „К” доля жовтку більша на 0,89$1,95 \%$ (Р>0,95-0,999), ніж у гібридів. У курей групи „К-1” уміст жовтку більший на 1,06 \% (P>0,95) порівняно з ровесницями групи „К-2”.

Таблиця 3

Морфологічні ознаки яєць гібридних курей $\mathrm{F}_{1}$ групи „К-2”

\begin{tabular}{|l|c|c|c|c|}
\hline \multicolumn{1}{|c|}{ Показники } & $\bar{X}$ & $\pm S_{\bar{X}}$ & $\delta$ & $\mathrm{Cv}, \%$ \\
\hline Маса яєць, г & 52,06 & 0,69 & 5,13 & 9,85 \\
\hline Індекс форми, \% & 78,67 & 0,36 & 2,82 & 3,58 \\
\hline Маса білка, г & 31,86 & 0,55 & 4,15 & 13,03 \\
\hline Індекс білка, \% & 13,37 & 0,31 & 2,40 & 17,95 \\
\hline Доля білка, \% & 61,05 & 0,38 & 2,84 & 4,65 \\
\hline Маса жовтку, г & 13,43 & 0,16 & 1,21 & 9,01 \\
\hline Індекс жовтку, \% & 51,89 & 0,41 & 3,17 & 6,11 \\
\hline Доля жовтку, \% & 25,92 & 0,32 & 2,43 & 9,37 \\
\hline Співвідношення білок/жовток & 2,38 & 0,05 & 0,34 & 14,29 \\
\hline Маса шкаралупи, г & 6,88 & 0,12 & 0,95 & 13,81 \\
\hline Доля шкаралупи, \% & 13,03 & 0,17 & 1,25 & 9,59 \\
\hline
\end{tabular}

Вісник Сумського національного аграрного університету 
Найбільше значення співвідношенням маси білка до маси жовтку характерне для гібридів $\mathrm{F}_{1}$ групи „К-2” (2,38), що більше на 6,25-11,74 \% (P>0,95-0,999), ніж в іншої птиці. Гібриди групи „К-1” також переважають м'ясо-яєчних курей за цією ознакою на 5,16 \% ( $P>0,95)$.

Отже, проведений порівняльний аналіз морфологічних ознак яєць курей дослідних груп дозволив встановити

Проведено також порівняльний аналіз морфологічних ознак яєць курей м'ясо-яєчної субпопуляції „К” $\left(F_{11}\right)$ вихідної материнської форми, гідридів другого покоління $\left(\mathrm{F}_{2}\right)$ груп „К-11” і „К-22”, отриманих за зворотного схрещування генотипові відмінності та специфічні особливості птиці.

$\left(F_{3 в}\right)$ груп „К-51” і „К-32” та синтетичної популяції „К-5” (табл. 4-9).

Одним із головних показників якості яєць є їх маса. 3і зміною маси яєць багато в чому змінюється і його якість [13]. У м'ясо-яєчних курей субпопуляції „К” маса яєць більша на 1,5 г (або 2,84 \%, Р>0,95), ніж у гібридів $F_{2}$ групи „К-22”. У „кобівської” птиці $F_{2}$ групи „К-11” яйця були важчими на 1,321,49 г (2,49-2,82 \%, Р>0,95-0,99) порівняно 3 „росівською” груп „К-22” та „К-32”. Взагалі, відмічається тенденція переважання „кобівської” птиці над „росівською” за даною ознакою.

Таблиця 4

Морфологічні ознаки яєць м'ясо-яєчних курей субпопуляції „К”, $\mathrm{F}_{11}$

\begin{tabular}{|c|c|c|c|c|}
\hline Показники & $\bar{X}$ & $\pm S_{\bar{X}}$ & $\delta$ & $\mathrm{Cv}, \%$ \\
\hline Мaca яєць, г & 54,31 & 0,48 & 3,52 & 6,48 \\
\hline Індекс форми, \% & 77,37 & 0,41 & 2,98 & 3,85 \\
\hline Маса білка, г & 32,68 & 0,42 & 3,09 & 9,45 \\
\hline Індекс білка, \% & 11,72 & 0,33 & 2,42 & 20,65 \\
\hline Доля білка, \% & 60,10 & 0,37 & 2,67 & 4,44 \\
\hline Маса жовтку, г & 14,28 & 0,26 & 1,17 & 8,19 \\
\hline Індекс жовтку, \% & 52,65 & 0,37 & 2,66 & 5,05 \\
\hline Доля жовтку, \% & 26,35 & 0,29 & 2,10 & 7,97 \\
\hline Співвідношення білок/жовток & 2,30 & 0,04 & 0,29 & 12,61 \\
\hline Маса шкаралупи, г & 7,34 & 0,10 & 0,70 & 9,54 \\
\hline Доля шкаралупи, \% & 13,55 & 0,18 & 1,31 & 9,67 \\
\hline
\end{tabular}

У гібридів груп „К-32” і „К-11” яйця виявилися довшими на 1,10-1,17 мм (2,02-2,15\%, Р>0,95-0,99) порівняно 3 особинами м'ясо-яєчної субпопуляції. На подовжній діаметр яєць генотип вплинув на $13,98 \%$ ( $\mathrm{P}<0,001)$.

У курей м'ясо-яєчної субпопуляції „К” індекс форми

Таблиця 5

Морфологічні ознаки яєць гібридних курей $\mathrm{F}_{2}$ групи „К-11”

\begin{tabular}{|c|c|c|c|c|}
\hline Показники & $\bar{X}$ & $\pm S_{\bar{X}}$ & $\delta$ & $\mathrm{Cv}, \%$ \\
\hline Мaca яєць, г & 54,30 & 0,42 & 4,92 & 9,06 \\
\hline Індекс форми, \% & 75,15 & 0,37 & 3,68 & 4,90 \\
\hline Маса білка, г & 32,70 & 0,38 & 1,74 & 5,32 \\
\hline Індекс білка, \% & 12,02 & 0,45 & 2,05 & 17,05 \\
\hline Доля білка, \% & 60,21 & 0,44 & 2,82 & 4,68 \\
\hline Маса жовтку, г & 14,73 & 0,28 & 1,29 & 8,76 \\
\hline Індекс жовтку, \% & 53,02 & 0,56 & 2,57 & 4,85 \\
\hline Доля жовтку, \% & 27,13 & 0,49 & 2,23 & 8,22 \\
\hline Співвідношення білок/жовток & 2,24 & 0,06 & 0,26 & 11,61 \\
\hline Маса шкаралупи, г & 6,87 & 0,10 & 0,44 & 6,40 \\
\hline Доля шкаралупи, \% & 12,66 & 0,16 & 1,75 & 13,82 \\
\hline
\end{tabular}

Морфологічні ознаки яєць гібридних курей $\mathrm{F}_{2}$ групи „К-22”

Таблиця 6

\begin{tabular}{|l|c|c|c|c|}
\hline \multicolumn{1}{|c|}{ Показники } & $\bar{X}$ & $\pm S_{\bar{X}}$ & $\delta$ & \multicolumn{1}{c|}{$\mathrm{Cv}, \%$} \\
\hline Маса яєць, г & 52,81 & 0,57 & 4,53 & 8,58 \\
\hline Індекс форми, \% & 74,89 & 0,51 & 3,71 & 4,99 \\
\hline Маса білка, г & 31,29 & 0,54 & 2,02 & 6,46 \\
\hline Індекс білка, \% & 11,79 & 0,47 & 1,77 & 15,01 \\
\hline Доля білка, \% & 59,24 & 0,53 & 2,95 & 4,98 \\
\hline Маса жовтку, г & 14,34 & 0,33 & 1,22 & 8,51 \\
\hline Індекс жовтку, \% & 52,07 & 0,77 & 2,87 & 5,51 \\
\hline Доля жовтку, \% & 27,13 & 0,44 & 2,64 & 9,73 \\
\hline Співвідношення білок/жовток & 2,19 & 0,05 & 0,21 & 9,59 \\
\hline Маса шкаралупи, г г & 7,19 & 0,21 & 0,79 & 10,99 \\
\hline Доля шкаралупи, \% & 13,63 & 0,23 & 1,61 & 11,81 \\
\hline
\end{tabular}

Маса яєць, їх довжина та ширина, індекс форми характеризувалися слабкою мінливістю $(2,46-9,06$ \%) й у гіб-

ридів, у більшості випадків, були більшими, ніж у м'ясояєчних курей.

Вісник Сумського національного аграрного університету 
За висотою й індексу білка значної відмінності між птицею різних груп не встановлено. Відчутним був вплив генотипу на ці ознаки - відповідно $12,60 \%(P<0,001)$ та $15,06 \%(P<0,001)$.

Маса білка у м'ясо-яєчних курей і гібридів $F_{2}$ групи „К11" була більшою на 1,40-1,43 г (P>0,95-0,99) порівняно з гібридами групи „К-22”. Відмічається тенденція переважання „кобівської” птиці за масою білка над „росівською”. Маса білка вирізнялася слабкою мінливістю ( $\mathrm{Cv}=5,32-9,45 \%$ ), тоді як висота та індекс білка вирізнялися середньою мінливістю $(\mathrm{Cv}=11,92-21,40 \%)$.

Морфологічні ознаки яєць гібридних курей $\mathrm{F}_{2}$ групи „К-51”

Таблиця 7

\begin{tabular}{|l|c|c|c|c|}
\hline \multicolumn{1}{|c|}{ Показники } & $\bar{X}$ & $\pm S_{\bar{X}}$ & $\delta$ & \multicolumn{1}{c|}{ Cv, \% } \\
\hline Маса яєць, г & 53,16 & 0,56 & 4,53 & 8,52 \\
\hline Індекс форми, \% & 76,05 & 0,34 & 2,28 & 3,00 \\
\hline Маса білка, г & 32,23 & 0,52 & 2,75 & 8,53 \\
\hline Індекс білка, \% & 11,55 & 0,31 & 1,64 & 14,20 \\
\hline Доля білка, \% & 60,61 & 0,23 & 3,24 & 5,35 \\
\hline Маса жовтку, г & 14,18 & 0,27 & 1,42 & 10,01 \\
\hline Індекс жовтку, \% & 52,63 & 0,49 & 2,59 & 4,92 \\
\hline Доля жовтку, \% & 26,65 & 0,31 & 2,13 & 7,99 \\
\hline Співвідношення білок/жовток & 2,28 & 0,03 & 0,24 & 10,53 \\
\hline Маса шкаралупи, г & 6,78 & 0,13 & 0,69 & 10,18 \\
\hline Доля шкаралупи, \% & 12,74 & 0,19 & 1,70 & 13,34 \\
\hline
\end{tabular}

На якість жовтку впливають різні фактори: годівля і утримання птиці, її вік, генотип (порода, лінія, крос), індивідуальні особливості птахів [14]. За масою жовтку вірогідної різниці між курми різного генезису не досягнуто. Найбільшою була у „кобівської” птиці групи „К-11” й перевага над іншими групами становила 2,72-3,88 \%. За відносним умістом жовтку простежується тенденція до більшого його умісту у гібридів $F_{2}$ груп „К-11” і „К-22”. На масу жовтку генотип вплинув на $12,96 \%(P<0,001)$.

Якісні показники жовтку мали слабкі коефіцієнти мін- ливості (3,26-10,01\%) й у гібридних курей були дещо більшими, ніж у м'ясо-яєчних субпопуляції „К”.

Одним із найважливіших показників якості яєць є товщина шкаралупи, як найбільш точний якісний показник її міцності, яка може коливатися від 200 до 500 мкм [5]. Чим товща шкаралупа в певних межах, тим краща виводимість яєць [15]. У м'ясо-яєчної птиці субпопуляції „К” маса шкаралупи більша на 0,47-0,59 г ( $P>0,99-0,999)$ порівняно з курми груп „К-11”, „К-51” і „К-32”. У гібридів $\mathrm{F}_{2}$ групи „К-22” вона важча на 0,44 г (P>0,95), ніж у птиці групи „К-32”.

Таблиця 8

Морфологічні ознаки яєць гібридних курей $\mathrm{F}_{2}$ групи „К-32”

\begin{tabular}{|l|c|c|c|c|}
\hline \multicolumn{1}{|c|}{ Показники } & $\bar{X}$ & $\pm S_{\bar{X}}$ & $\delta$ & $\mathrm{Cv}, \%$ \\
\hline Маса яєць, г & 52,98 & 0,55 & 3,53 & 6,66 \\
\hline Індекс форми, \% & 74,54 & 0,50 & 2,34 & 3,14 \\
\hline Маса білка, г & 31,89 & 0,52 & 2,45 & 7,68 \\
\hline Індекс білка, \% & 11,73 & 0,53 & 2,51 & 21,40 \\
\hline Доля білка, \% & 60,18 & 0,45 & 3,10 & 5,15 \\
\hline Маса жовтку, г & 14,34 & 0,29 & 1,34 & 9,34 \\
\hline Індекс жовтку, \% & 52,93 & 0,67 & 3,15 & 5,95 \\
\hline Доля жовтку, \% & 27,04 & 0,34 & 2,58 & 9,54 \\
\hline Співвідношення білок/жовток & 2,24 & 0,04 & 0,30 & 13,39 \\
\hline Маса шкаралупи, г & 6,75 & 0,13 & 0,60 & 8,89 \\
\hline Доля шкаралупи, \% & 12,78 & 0,24 & & 1,15 \\
\hline
\end{tabular}

Доля шкаралупи у м'ясо-яєчних курей субпопуляції „K” і гібридів $F_{2}$ групи „К-22” більша на 0,79-0,98 \% (P>0,950,99), ніж у гібридів інших трьох груп. На масу шкаралупи генотип курей впливав на 7,86 \% (P<0,001), на долю шкаралупи $-6,07 \%$.

Визначено показники якості яєць і у м'ясо-яєчних курей синтетичної популяції „К-5”, утвореної внаслідок об'єднання птиці різних генотипових груп (табл. 9). Взагалі, показники якості яєць відповідали усталеним вимогам до них, зазначеним у методичних рекомендаціях з інкубації яєць курей [9].

Таблиця 9

Морфологічні ознаки яєць м'ясо-яєчних курей популяції „К-5”

\begin{tabular}{|c|c|c|c|c|}
\hline Показники & $\bar{X}$ & $\pm S_{\bar{X}}$ & $\delta$ & $\mathrm{Cv}, \%$ \\
\hline Маса яєць, г & 57,55 & 0,56 & 3,06 & 5,32 \\
\hline Індекс форми, \% & 75,74 & 0,51 & 2,82 & 3,72 \\
\hline Маса білка, г & 34,84 & 0,58 & 3,16 & 9,08 \\
\hline Індекс білка, \% & 10,82 & 0,33 & 1,83 & 16,91 \\
\hline Доля білка, \% & 60,45 & 0,52 & 2,85 & 4,71 \\
\hline Маса жовтку, г & 15,34 & 0,20 & 1,10 & 7,17 \\
\hline Індекс жовтку, \% & 47,16 & 0,59 & 3,24 & 6,87 \\
\hline Доля жовтку, \% & 26,71 & 0,41 & 2,27 & 8,50 \\
\hline Співвідношення білок/жовток & 2,29 & 0,06 & 0,30 & 13,10 \\
\hline Маса шкаралупи, г & $7,2,37$ & 0,15 & 0,83 & 11,26 \\
\hline
\end{tabular}

Вісник Сумського національного аграрного університету 
Маса яєць у курей створеної синтетичної популяції „К-5” більша на 3,24-7,15 г (Р>0,999), ніж у птиці інших досліджених груп. Більша маса яєць визначила відповідно і вищі значення деяких морфологічних ознак. Так, кури групи „К-5” переважали м'ясо-яєчну птицю субпопуляції „К” $\left(\mathrm{F}_{11}\right)$ за подовжнім діаметром яєць (на 1,17 мм, Р>0,95), але поступалися за індексом форми (на 1,63 \%, Р>0,95).

У курей створеної синтетичної популяції „К-5” абсолютна маса білка більша на 2,14-3,55 г ( $P>0,99-0,999)$, ніж у птиці інших груп. Хоча, за відносним умістом білка в яйцях вірогідної різниці не досягнуто.

У курей групи „К-5” менший індекс жовтку на 4,915,86 \% (P>0,999), ніж в інших групах. Проте, його маса біль- ша на 1,0-1,16 г (або 6,97-8,18 \%, Р>0,95-0,99), крім групи „К$11 "$.

Доля шкаралупи менша на 0,71\% (P>0,95), ніж у м'ясо-яєчних субпопуляції „К” та на 0,79 \% (P>0,95) порівняно 3 групою „К-22”.

Висновки. Проведений порівняльний аналіз цілого комплексу морфологічних ознак яєць курей різного генезису дав змогу встановити, з одного боку, специфічні генотипові особливості птиці досліджених груп за широким рядом якісних показників яєць, а з іншого, - виявити ймовірні відмінності між птицею різних генотипових груп за вивченими кількісними ознаками.

\section{Список використаної літератури:}

1. Безусова А., Хмельницкая Т., Саппинен С. Селекция на повышение воспроизводительных качеств птицы. Птицеводство. 2006. №11. С. 26-29.

2. Дядичкина Л. Качество яиц - залог успешной инкубации. Птицеводство. 2008. №3. С. 21-23.

3. Дядичкина Л. Качество яиц - залог успешной инкубации. Сучасне птахівництво. 2008. №7-8 (68-69). С. 39-42.

4. Станишевская О. Повышение качества инкубационных яиц. Птицеводство. 2008. №9. С. 15-17.

5. Штеле А. Л. Куриное яйцо: вчера, сегодня, завтра. М.: Агробизнесцентр, 2004. 196 с.

6. Фисинин В. И., Егорова А. В., Елизаров Е. С. Резервы повышения выхода мяса от мясных кур методами племенной работы: методические рекомендации. Сергиев Посад, 2005. 47 с.

7. Кавтарашвили А. Ш. Как управлять массой яиц в промышленном птицеводстве ? Ефективне птахівництво. 2008. №4(40). C. 38-40.

8. Бондаренко Ю. В., Хвостик В. П. Покращення продуктивності м'ясо-яєчних курей вітчизняної селекції. Вісник СНАУ. Серія „Тваринництво”. 2020. Випуск 2(41). С. 29-32.

9. Прокудина Н. А., Артеменко А. Б., Огурцова Н. С. Методы биологического контроля в инкубации. Харьков: ООО "HTMT", 2006. 107 c

10. Бородай В. П., Пономаренко Н. П., Мельник В. В. Якість і безпека харчових яєць. Сучасне птахівниитво. 2006. №11. C. 11-13

11. Прокудіна Н. Якість перепелиних яєць. Наше птахівництво. 2020. №6. С. 22-23.

12. Дядичкина Л. Ф., Позднякова Н. С., Кривопишин И. П. Пособие по биологическому контролю при инкубации яиц сельскохозяйственной птицы. Сергиев Посад, 1992. 57 с.

13. Коваленко Г., Степаненко І. Шляхи підвищення якості курячих яєць. Пропозиція. 2005. №6. С. 122-123.

14. Статнік І. Я., Коновал Л. М., Коваленко Г. Т. Порівняльний аналіз якості яєць батьківського стада кросу "Хай Лайн W36" в початковий період яйцекладки. Птахівництво.. 2008. Вип. 61. С. 162-175.

15. Подстрєшний О. П., Коваленко Г. Т., Бородай В. П. Характеристика якості інкубаційних яєць курей кросів „Хайсекс білий” і „Хайсекс коричневий”. Сучасне птахівництво. 2007. №10-11. С. 8-12.

\section{References:}

1. Bezusova A., Hmel'nickaja T., Sappinen S. Selekcija na povyshenie vosproizvoditel'nyh kachestv pticy. Pticevodstvo. 2006. №11. S. 26-29.

2. Djadichkina L. Kachestvo jaic - zalog uspeshnoj inkubacii. Pticevodstvo. 2008. №3. pp. 21-23.

3. Djadichkina L. Kachestvo jaic - zalog uspeshnoj inkubacii. Suchasne ptaxivny 'cztvo. 2008. №7-8 (68-69). pp. 39-42.

4. Stanishevskaja O. Povyshenie kachestva inkubacionnyh jaic. Pticevodstvo. 2008. №9. S. 15-17.

5. Shtele A. L. Kurinoe jajco: vchera, segodnja, zavtra. M.: Agrobiznescentr, 2004. 196 p.

6. Fisinin V. I., Egorova A. V., Elizarov E. S. Rezervy povyshenija vyhoda mjasa ot mjasnyh kur metodami plemennoj raboty: metodicheskie rekomendacii. Sergiev Posad, 2005. 47 p. S. $38-40$.

7. Kavtarashvili A. Sh. Kak upravljat' massoj jaic v promyshlennom pticevodstve. Efekty’vne ptaxivny`cztvo. 2008. №4(40).

8. Bondarenko Yu. V., Xvosty`k V. P. Pokrashhennya produkty`vnosti m'yaso-yayechny`x kurej vitchy`znyanoyi selekciyi. Visny`k SNAU. Seriya „Tvary 'nny'cztvo”. 2020. Vy'pusk 2(41). pp. 29-32.

9. Prokudina N. A., Artemenko A. B., Ogurcova N. S. Metody biologicheskogo kontrolja v inkubacii. Har'kov: OOO "NTMT", 2006. $107 \mathrm{~s}$

10. Borodaj V. P., Ponomarenko N. P., Mel’ny`k V. V. Yakist` i bezpeka xarchovy`x yayecz`. Suchasne ptaxivny`cztvo. 2006. №11. pp. 11-13.

11. Prokudina N. Yakist’ perepely’ny’x yayecz`. Nashe ptaxivny`cztvo. 2020. \#6. S. 22-23.

12. Djadichkina L. F., Pozdnjakova N. S., Krivopishin I. P. Posobie po biologicheskomu kontrolju pri inkubacii jaic sel'- 
skohozjajstvennoj pticy. Sergiev Posad, 1992. 57 p.

13. Kovalenko G., Stepanenko I. Shlyaxy` pidvy’shhennya yakosti kuryachy’x yayecz`. Propozy’ciya. 2005. №6. pp. 122123.

14. Statnik I. Ya., Konoval L. M., Kovalenko G. T. Porivnyal'ny’j analiz yakosti yayecz’ bat kivs`kogo stada krosu "Xaj Lajn W36" v pochatkovy’j period yajcekladky'. Ptaxivny'cztvo. 2008. Vy`p. 61. pp. 162-175.

15. Podstryeshny`j O. P., Kovalenko G. T., Borodaj V. P. Xaraktery’sty`ka yakosti inkubacijny`x yayecz` kurej krosiv „Xajseks bily j’” i „Xajseks kory’chnevy’j”. Suchasne ptaxivny’cztvo. 2007. №10-11. pp. 8-12. NAAS

Khvostik Victor Pavlovich, Doctor of Agricultural Sciences, Institute of Animal Breeding and Genetics nd. a. M.V.Zubets of

Bondarenko Yuriy Vasyleevich, Doctor of Biological Sciences, Professor, Sumy National Agrarian University

Qualitative indicators of eggs of meat and egg chickens of different genesis

A wide range of morphological features of eggs of hens of the original maternal form, descendants of the first-second generations, created synthetic population in the study of the effectiveness of crossing roosters of imported meat crosses with meat-egg females of domestic selection. Qualitative indicators of eggs in the amount of 30 pieces from each genotypic group of chickens were determined at the age of 30 weeks. In hens of the original maternal form, traits such as egg weight, egg and yolk diameters, yolk height, yolk weight, and relative proportion were probably greater than those of first-generation offspring. Whereas, in the first generation hybrids, the height of the protein, the protein index and its mass were characterized by higher values compared to the chickens of the original maternal form. In the offspring of the second generation, whose parents were Cobb-500 cross cocks, the weight of eggs and protein was greater than that of their peers, for which Ross-308 cross males were used. In meat and egg hens of the original form, the form index is higher by 2.11-2.86\% ( $P>0.95-0.99)$ compared with F2 hybrids. The weight of eggs, their length and width, the shape index were characterized by low variability (2.46-9.06\%) and in the offspring of F2, in most cases, were greater than in meat and egg hens of domestic selection. There is no significant difference in height and protein index between birds of different F2 groups. By weight of the yolk, a probable difference between chickens of different genesis F2 is not achieved. The yolk mass was affected by genotype by $12.96 \%$ ( $P<0.001)$. The quality of the yolk had low coefficients of variability $(3.26-10.01 \%)$ and in F2 hybrid chickens were slightly higher than in the meat-egg subpopulation " $K$ ". In meat-egg birds of the original maternal form, the weight of the shell is greater by 0.47-0.59 g (P> 0.99-0.999) compared with the offspring of the second generation. In chickens of the created synthetic population the big weight of eggs defined accordingly and higher values of some morphological signs. Significant differences with birds of other genotypic groups in longitudinal egg diameter, shape index, absolute protein mass, yolk index, yolk mass, shell share were noted.

Key words: meat and egg hens, crossbreeding, egg quality, morphological features, protein, yolk, shell.

Дата надходження до редакції: 14.09.2020 р. 